\title{
Yöneticilerin Etik Karar Verme Durumları Üzerine Bir Araştırma
}

\author{
Adem ÖZDEMİRa, ${ }^{a, b}$ Abdullah KARAKAYA ${ }^{c}$
}

Özet

Anahtar Kelimeler

$\mathrm{Bu}$ araştırmanın amacı üniversitede yönetici düzeyinde görev yapan Etik personelin etik karar verme durumlarının birtakım değişkenler açısından farklılık gösterip göstermediğini araştırmaktır. Tanımlayıcı nitelikte olan bu araştırmada veri toplama yöntemi olarak anket tekniğinden yararlanılmıştır. Araştırmada veri toplama aracı olarak, "etik karar verme ölçeği" ve "kişisel bilgi formu" kullanılmıştır. Elde edilen verilerin analizinde, iki grup arasındaki karşılaştırmalar için Mann-Whitney U Testi ve çok gruplu karşılaştırmalar için Kruskal-Wallis Varyans Analizi kullanılmıştır. Çoklu karşılaştırmalarda Kruskal Wallis Varyans Analizi sonucu anlamlı farkın çıktığı durumlarda, bu farkın hangi gruplar arasından kaynaklandığını belirlemek için Mann Whitney U Testi uygulanmıştır. Demografik verilere ilişkin verilerin analizinde ise frekans ve yüzde yöntemleri kullanılmıştır. Araştırma soncunda, üniversitede yönetici düzeyinde görev yapan personelin etik karar verme algılarının cinsiyet değişkenine göre anlamlı düzeyde farklılık göstermediği $(\mathrm{p}=0,130>0,05)$, medeni durum açısından iş birliği alt boyutunda $(p=0,049<0,05)$ anlamlı farklılık gösterdiği görülmüştür. Yine eğitim durumu değişkenine göre etik karar verme $(p=0,020<0,05)$, sevgi alt boyutu $(\mathrm{p}=0,034<0,05)$ ve adalet alt boyutu $(\mathrm{p}=0,017<0,05)$ açısından anlamlı düzeyde farklılık gösterdiği sonucuna ulaşılmıştır.

\section{A Research on Managers' Perception of Ethical Decision Making}

\begin{abstract}
The aim of this study is to investigate whether the ethical decision-making status of the staff working at the university's executive level differs in terms of some variables. In this descriptive study, the questionnaire technique was used as a data collection method. "Ethical decision making scale" and "personal information form" were used as data collection tools in the study. In the analysis of the data obtained, Mann-Whitney U Test was used for comparisons between two independent groups and Kruskal Wallis Variance Analysis for multi-group comparisons. In cases where a significant difference was found as a result of Kruskal Wallis Variance Analysis in multiple comparisons, Mann Whitney U Test was used to determine which groups this difference originated from. Frequency and percentage methods were used in the analysis of the data regarding demographic data. As a result of the study, it was seen that the perceptions of ethical decision-making of the staff working at the university administration level did not differ significantly according to the gender variable $(p=0.130>0.05)$, and there was a significant difference in the subdimension of cooperation in terms of marital status $(\mathrm{p}=0.049<0.05)$. It was also concluded that there was a significant difference in terms of ethical decision making $(p=0.020<0.05)$, affection sub-dimension $(p=0.034<0.05)$ and justice sub-dimension $(p=0.017<0.05)$ according to the educational level variable .
\end{abstract}

Keywords

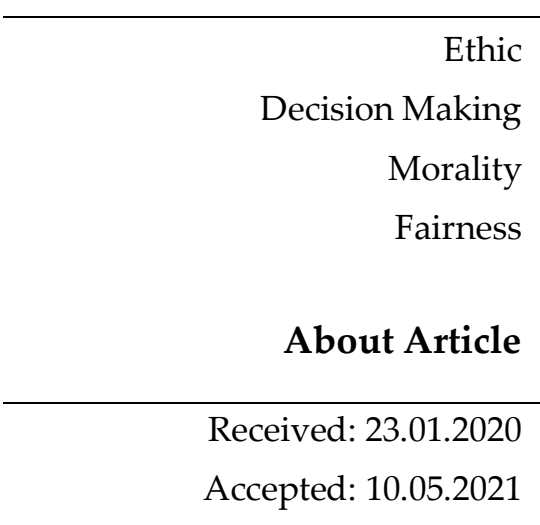

Doi: 10.18026/cbayarsos.678981

\section{a aozdemir@agri.edu.tr}

b Öğretim Görevlisi, Ağrı İbrahim Çeçen Üniversitesi, Eleşkirt MYO, Finans, Bankacılık ve Sigortacılık Bölümü, Orcid: 0000-0003-3127-6846.

c Prof. Dr., Karabük Üniversitesi, İktisadi ve İdari Bilimler Fakültesi, İletme Bölümü, Orcid: 0000-0002-3214-6771. 


\section{Giriş}

Etik kavramı son zamanlar hem özel hem de kamu sektörü tarafından ilgi çekici bir konu haline gelmiştir. İnsanlar çalıştıkları alanda karar alırken, aldıkları kararın etik olup olmadığını da sorgulamaya başlamıştır. Etik, ahlâk, işi iyi ve doğru yapma son zamanlarda giderek önem kazanan unsurlar olmaya başlamıştır.

Etik kavramı ve tartışılmaya başlanması çok eski dönemlere kadar dayanmaktadır. İnsanoğlu, yaratıldığı günden bu yana pek çok problemle karşılaşmış ve bu problemlerin çözümü konusunda fikirlerde ayrılıklar yaşamışlardır. Başa gelen problemler insan ilişkilerini etkileyerek zamanla toplumsal sorunlara, hatta toplumsal yıkımlara neden olmuştur (Erim, 2018). Etik kavramı; Yunancadan günümüze kadar gelmiş bir kelimedir. Kelimenin Yunanca töre, karakter ve alışkanlık anlamındaki "ethos" sözcügünden türetilmiş bir kavramdır. Bu sözcük temelinde iyi-kötü, doğru-yanlış ile ilgili değerler ve kurallar anlamında kullanılmaktadır (Eryılmaz, 2015).

Etik terimi yanlış ile doğruyu birbirinden ayırmak için ahlâk ile bütünleşen bir kavramdır. Etik kavramı "doğru veya yanlış" ile "iyi veya kötü" kabul edilenlerle insan davranışlarına yön veren kurallar bütünüdür (Gökçearslan Çiftçi ve Gönen 2011). Etik ve ahlâk birbirinin yerine kullanılmakla birlikte aslında birbirinden farklı kavramlardır. Etik doğru ve yanlış davranışların teorisi sayılırken ahlâk ise bunların pratik kısmını oluşturmaktadır (Billington, 2011).

Bir başka görüşe göre ise etik, olması gereken insan karakterinin yani ideal olanın temsil ettiği ilkeleri tartışan bir felsefe disiplinidir. Etik bir davranışın doğru ya da yanlış olması üzerinde durur ve bireylerin bulundukları konumları ve inançlarını tutarlı bir şekilde önermelerle gerçekleştirmelerini ister (Lo, 1995). Bu bağlamda çalışanların işlerini yaparken yanlışıdoğruyu ve iyiyi-kötüyü ayırt etmeleri davranışları açısından önem arz etmektedir. Genel anlamda kararlar alırken daha etik davranmaları gerekli bir durum olarak görülmektedir. Karar verme, herhangi bir faaliyetle ilgili çeşitli olasılıklar ve alternatifler içerisinden uygun olan birisinin seçilmesi anlamı taşımaktadır. Karların önemli ya da önemsiz olması yaşam düzenini etkilemede sorun teşkil etmez. Karar verme işlemleri yönetim ile alakalı bir takım süreç olup yönetim sürecinin bir alt sistemi içerisinde yer almaktadır. İnsanlar amaçları, standartları, kaynak bulma faaliyetleri ve yaşantılarında önemli değerler için karar verme sürecine girerler (Gönen, 2002). Kamu kurum ve kuruluşlarında ya da bireyler kendi yaşamlarında kararlar verirken etik ilklere göre davranmaları gerektiği düşünülmektedir.

Etik kararlar insan mutluluğunun artırılması ve gerekli ihtiyaçların karşılanması gibi konuların ele alındığı refahla ilgili bir olgudur. Etik kararlar daha önce verilmiş ve gelecekteki alınacak kararlarla tutarlılık göstermelidir (Banks, 2006). Yani genel olarak bakıldığında etik ve karar verme arasında iyi-kötü ve doğru-yanlış olgularının ayırt edilmesi gerekmektedir. Bu ayrım da insanların davranışlarına ve iş düzenlerine yansıyacağı açık ve önemlidir ve göz ardı edilmemesi gereken bir durumdur. Bu açıdan araştırma Ağrı İbrahim Çeçen Üniversitesi'nde yönetici düzeyinde görev yapan personelin etik karar verme durumlarının çeşitli değişkenler açısından farklılık gösterip göstermediğinin belirlenmesi amacıyla yapılmıştır. 
Araştırmanın kavramsal çerçeve bölümünde etik ve etik karar verme kavramları üzerinde durulmuş, daha sonra araştırmanın amacı, kapsamı, yöntemi ve bulgularından bahsedilmiştir. Son bölümde ise sonuç ve önerilere yer verilmiştir.

\section{Etik}

\section{Kavramsal Çerçeve}

Etik kavramı yanlışı doğrudan ayırmak için ahlâk kavramını anlamaya çalışır. Etik kavramı 'doğru veya yanlış' ile 'iyi veya kötü' kabul edilen şeylerle insan davranışlarına yön veren standart ve kurallar bütünüdür. Etik kişisel ve toplumsal hayattaki ahlâki seçimleri yansitmaktadır (Gökçearslan Çifçi ve Gönen, 2011, s.150). Etik iyi veya kötünün ne olduğu, doğru ve yanlışı belirleyen özellikler olarak tanımlanırken doğru olan şeyin etik, yanlış olanın ise etik dışı olarak belirlendiği değerlerdir ve bizim neyi yapmamız neyi yapmamamız gerektiğini belirtmektedir. Ahlâk felsefesi açısından etik, kişilerin hem kendi yaşamlarında hem de topluluk içerisinde amaçlarına ulaşmak için gösterdikleri davranışları inceleyen bu davranışların iyi-kötü, yanlış-doğru şeklinde anlaşılmasını sağlayan sistematik sistemdir. Etik bireylerin gösterdikleri davranışlara temel oluşturan ahlâk ilkelerinin tamamıdır (Sabuncuoğlu, 2011, s.2-3).

Etik ve ahlâk arasında temel bir ayrım vardır. Ahlâk fiilen ve tarihsel açıdan bireysel, grupsal ve toplumsal düzeyde dahil olmak üzere yaşanan bir olgudur. Etik ise, bu olguyu ele alan ahlâk görüş ve öğretilerini sınıflandıran aralarında oluşan benzerlik ve farklılıkları karşılaştırıp eleştiren ve bunları ortaya koyan felsefe disiplininin adıdır (Daşdan, Belikli, Bayraktar, 2015, s.77).

\section{Etik Karar Verme}

Etik kararları diğer kararlardan farklı kılan, karar veren kişinin karar verme sorumluluğunu alması ve daha önce karşılaşmadığı bir konu ile ilgili karar verecek olmasıdır. Karar verecek kişi böyle bir durumda sahip olduğu değerleri göz önüne almaktadır. Bu yüzden kişisel değer ve yargılar etik karar verirken önemlidir (Gerçek, 2017, s.954).

Etik karar alma süreci, etik ilke ve kuralların yarattığ kültürel, sosyal, kişisel ve toplumsal eğilimleriyle de alakalıdır (Daşdan, Belikli, Bayraktar, 2015, s.65). Bir etkinliğin veya davranışın değişik sonuçlarını etik ilkelere göre göz önüne alan kişi seçim yapma sürecinde üstlendiği rol veya diş çevresel faktörlerden etkilenebilmektedir (Özdemir, 2009, s.132-138). Etik teoriler, karar ya da eylemde yer alan çeşitli tarafların farklı ahlâki varsayımlarının açığa çıkmasına yardımcı olacaktır. Firmaların etik değerlendirmesinde bazı öznellikler yer alabilir. Etik kuramlar, zaman içinde ülkelerde endüstri ve iş etiği arasındaki etik politikalarını analiz etmek için de kullanılabilir.

\section{Yöntem}

\section{Araştırmanın Amacı ve Kapsamı}

Bu araştırma Ağrı İbrahim Çeçen Üniversitesi'nde yönetici düzeyinde görev yapan personelin etik karar verme durumlarının çeşitli değişkenler açısından farklılık gösterip göstermediğinin belirlenmesi amacıyla yapılmıştır. Araştırma yönetici düzeyinde çalışan personellerin etik karar verme durumlarını etkilediği düşünülen; cinsiyet, medeni durum, yaş, eğitim, unvan, 
daha önce etik dersi almış olmak gibi demografik faktörlerin etik karar verme süreçlerine etkisinin araştırılmasına yönelik yapılmıştır. Araştırmada aşağıdaki hipotezler test edilmiştir.

H1: Ağr1 İbrahim Çeçen Üniversitesi' nde yönetici düzeyinde görev yapan personellerin etik karar vermesi cinsiyete göre değişkenlik göstermektedir.

H2: Ağrı İbrahim Çeçen Üniversitesi' nde yönetici düzeyinde görev yapan personellerin etik karar vermesi medeni duru göre değişkenlik göstermektedir.

H3: Ağrı İbrahim Çeçen Üniversitesi' nde yönetici düzeyinde görev yapan personellerin etik karar vermesi daha önce etik dersi alma durumuna göre değişkenlik göstermektedir.

H4: Ağrı İbrahim Çeçen Üniversitesi' nde yönetici düzeyinde görev yapan personellerin etik karar vermesi yaşa göre değişkenlik göstermektedir.

H5: Ağrı İbrahim Çeçen Üniversitesi' nde yönetici düzeyinde görev yapan personellerin etik karar vermesi yaptıkları göreve göre değişkenlik göstermektedir.

H6: Ağrı İbrahim Çeçen Üniversitesi' nde yönetici düzeyinde görev yapan personellerin etik karar vermesi eğitim durumuna göre değişkenlik göstermektedir.

\section{Evren ve Örneklem}

Araştırmanın evrenini Ağrı İbrahim Çeçen Üniversitesi' nde yönetici düzeyinde görev yapan toplam 83 personel oluşturmaktadır. Fakat çalışma gönüllük esasına dayalı yapıldığından ankete katılmak istemeyenlerin ve anket uygulaması esnasında yerinde bulunmayan personellerin olması nedeniyle araştırmanın örneklem grubunu 63 erkek, 5 kadın toplamda 68 kişi oluşturmaktadır. Örneklem grubunun tespitinde araştırmalarda sıklıkla kullanılan basit tesadüfi örnekleme yöntemi kullanılmıştır.

Araştırmada, bir evren içinden seçilen bir örneklem üzerinde yapılan çalışmalar yoluyla evren genelindeki eğilim, tutum veya görüşlerin nicel veya nümerik olarak betimlenmesini sağlayan tarama deseni kullanılmıştır (Creswell, 2013). Araştırmada veri toplama tekniği olarak anket tekniğinden yararlanılmıştır (Erkuş, 2013).

\section{Araştırmanın Sınırlılıkları}

Araştırmanın Ağrı İbrahim Çeçen Üniversitesi ile sınırlı kalması ve anket çalışması yapıldığında çalışma yerinde olmayan ya da izinde olan personellere ulaşılamaması çalışmanın kısıtlarını oluşturmaktadır.

\section{Veri Toplama Araçları ve Analiz Yöntemi}

Araştırmada Ağrı İbrahim Çeçen üniversitesinde çalışan yönetici düzeyindeki personellerden anket yöntemi ile elde edilen veriler kullanılırken veri toplama aracı olarak Kaya (2015) tarafından geliştirilen "etik karar verme ölçeği" ve "kişisel bilgi formu" kullanılmıştır. Verilerin nasıl bir dağılım gösterdiğini belirlemek amacıyla normallik testi yapılmış bu test sonuçlarına göre araştırmada parametrik olmayan testlerden yararlanılmıştır. Araştırmada iki gruplu karşılaştırmalar için Mann-Whitney U Testi ve çok gruplu karşılaştırmalar için 
Kruskal-Wallis Varyans Analizi kullanılmıştır. Çok gruplu karşılaştırmalarda Kruskal Wallis Varyans Analizi sonucu anlamlı farkın çıktığı durumlarda, bu farkın hangi gruplar arasından kaynaklandığını belirlemek için Mann Whitney U Testi uygulanmıştır. Araştırmada anlamlılık düzeyi için $p=0,05$ seçilmiştir.

\section{Bulgular}

$\mathrm{Bu}$ bölümde yapılan analizlere ilişkin bulgulara yer verilmiştir. Bulgular katılımcıların demografik özelliklerini ortaya koyan tanımlayıcı istatistikleri ve farklılık analizlerinin sonuçlarını içermektedir.

\section{Cronbach's Alpha Güvenilirlik Analizi}

Araştırmada kullanılan ölçeğin güvenilirlik düzeyini gösteren Cronbach's Alpha katsayıs1 ,953 çıkmıştır. Bu da ölçeğin oldukça güvenilir olduğunu göstermektedir.

\section{Demografik Özellikler (Tanımlayıcı İstatistikler)}

Bu kısımda demografik değişkenlere ilişkin frekans ve yüzdelik dağılımları verilmiştir.

Tablo 1. Demografik Değişkenlere İlişkin Frekans ve Yüzdelikler

\begin{tabular}{|c|c|c|c|}
\hline \multicolumn{2}{|c|}{ Demografik Değişkenler } & \multirow{2}{*}{$\begin{array}{l}\mathbf{N} \\
5\end{array}$} & \multirow{2}{*}{$\begin{array}{l}\% \\
7 \\
\end{array}$} \\
\hline & Kadın & & \\
\hline Cinsiyet & Erkek & 63 & 93 \\
\hline \multirow{3}{*}{ Yaş } & 25-34 Yaş & 14 & 20 \\
\hline & $35-45$ Yaş & 34 & 50 \\
\hline & 46-55 Yaş & 20 & 30 \\
\hline \multirow{12}{*}{ Görev } & Şube Müdürü & 17 & 19 \\
\hline & Daire Başkanı & 7 & 10 \\
\hline & Lab.ve Arş. Mrk. Md. Yrd. & 3 & 4 \\
\hline & Lab.ve Arş. Mrk. Md. & 8 & 11 \\
\hline & Enstitü Md. Yrd. & 2 & 3 \\
\hline & Enstitü Md. & 3 & 4 \\
\hline & MYO Md. Yrd. & 6 & 8 \\
\hline & MYO Md. & 6 & 8 \\
\hline & Yüksekokul Md. Yrd. & 5 & 7 \\
\hline & Yüksekokul Md. & 5 & 7 \\
\hline & Dekan Yrd. & 7 & 10 \\
\hline & Dekan & 3 & 4 \\
\hline
\end{tabular}




\begin{tabular}{llcc}
\hline \multirow{2}{*}{ Medeni Durum } & Bekar & 16 & 24 \\
& Evli & 52 & 76 \\
\hline & Üniversite (Önlisans-Lisans) & 33 & 48 \\
Eğitim Durumu & Üniversite (Lisansüstü) & 35 & 52 \\
\hline
\end{tabular}

Tablo 1' e göre; araştırmaya katılan akademik personelin 53'ünün (\%27) kadın, 141'inin (\%73) erkek, 21'inin (\%11) 25-29 yaş aralığında, 90'ının (\%46) 30-34 yaş aralığında, 64'ünün (\%33) 3539 yaş aralığında, 19'unun (\%10) 40-44 yaş aralığında olduğu görülmektedir. Tabloya göre araştırmaya katılan akademik personelin 12'sinin (\%6) profesör unvanına, 33'ünün (\%17) doçent unvanına, 47'sinin (\%24) doktor öğretim üyesi unvanına, 69'unun (\%36) öğretim görevlisi unvanına, 33'ünün (\%17) araştırma görevlisi unvanına sahip oldukları anlaşılmıştır. Tabloya göre araştırmaya katılan akademik personelin 60'ının (\%31) 0-4 yıl, 63'ünün (\%33) 59 y1l, 52'sinin (\%26) 10-14 yıl, 19'unun (\%10) 15 yıl ve üzeri toplam hizmet süresine sahip oldukları görülmektedir.

\section{Farklılık Analizlerine İlişkin Bulgular}

Araştırmanın bu kısmında cinsiyet, medeni durum, daha önce etik dersi alıp almama, yaş, görev ve eğitim seviyesi gibi fonksiyonel değişkenlere göre yapılan Mann Whitney U Testi ve Kruskal Wallis H Testlerine ilişkin analiz sonuçlarına yer verilmiştir.

Tablo 2. Araştırmaya Katılan Personellerin Etik Karar Verme Alt Boyutlarının Cinsiyete Göre Karşılaştırılması Gösteren Mann Whitney U Testi Sonuçları

\begin{tabular}{|c|c|c|c|c|c|c|}
\hline & Cinsiyet & $\mathbf{N}$ & Sira Ort. & Sira Top. & $\mathrm{U}$ & $p$ \\
\hline Etik Karar & Erkek & 63 & 33,47 & 2108,50 & \multirow{2}{*}{92,500} & \multirow{2}{*}{,130 } \\
\hline Verme & Kadın & 5 & 47,50 & 237,50 & & \\
\hline Sevgi & Erkek & 63 & 33,75 & 2126,50 & \multirow{2}{*}{110,000} & \multirow{2}{*}{,279 } \\
\hline Boyutu & Kadın & 5 & 44,00 & 220,00 & & \\
\hline Adalet & Erkek & 63 & 33,44 & 2107,00 & \multirow{2}{*}{91,000} & \multirow{2}{*}{,124 } \\
\hline Boyutu & Kadın & 5 & 47,80 & 239,00 & & \\
\hline \multirow{2}{*}{ İş birliği Boyutu } & Erkek & 63 & 33,75 & 2128,00 & \multirow{2}{*}{112,000} & \multirow{2}{*}{,300 } \\
\hline & Kadın & 5 & 43,60 & 218,00 & & \\
\hline
\end{tabular}

$\mathrm{p}=0,05$

Tablo 2 incelendiğinde araştırmaya katılan yönetici düzeyinde görev yapan personelin etik karar verme ölçeği ve ölçeğin alt boyutlarından sevgi boyutu ( $U=110,000 ; p=0,279>0.05)$, adalet 
boyutu ( $U=91,000 ; p=0,124>0.05)$ ve iş birliği boyutunun ( $U=112,000 ; p=0,300>0.05)$ cinsiyet değişkenine göre anlamlı düzeyde farklılaşmadığı belirlenmiştir. Bu yüzden H1 hipotezi ret olmuştur.

Tablo 3. Araştırmaya Katılan Personellerin Etik Karar Verme Alt Boyutlarının Medeni Duruma Göre Karşılaştırılması Gösteren Mann Whitney U Testi Sonuçları

\begin{tabular}{|c|c|c|c|c|c|c|}
\hline & $\begin{array}{l}\text { Medeni } \\
\text { Durum }\end{array}$ & $\mathbf{N}$ & Sira Ort. & Sira Top. & $\mathbf{U}$ & p \\
\hline \multirow{2}{*}{ Etik Karar Verme } & Bekar & 16 & 29,63 & 474,00 & \multirow{2}{*}{338,000} & \multirow{2}{*}{,258 } \\
\hline & Evli & 52 & 36,00 & 1872,00 & & \\
\hline \multirow{2}{*}{ Sevgi Boyutu } & Bekar & 16 & 31,75 & 508,00 & \multirow{2}{*}{372,000} & \multirow{2}{*}{, 517} \\
\hline & Evli & 52 & 35,35 & 1838,00 & & \\
\hline \multirow{2}{*}{ Adalet Boyutu } & Bekar & 16 & 33,38 & 534,00 & \multirow{2}{*}{398,000} & \multirow{2}{*}{ 785 } \\
\hline & Evli & 52 & 34,85 & 1812,00 & & \\
\hline \multirow{2}{*}{ İş birliği Boyutu } & Bekar & 16 & 26,13 & 418,00 & \multirow{2}{*}{372,000} & \multirow{2}{*}{$049^{*}$} \\
\hline & Evli & 52 & 37,08 & 1928,00 & & \\
\hline
\end{tabular}

$\mathrm{p}=0,05$

Tablo 3 incelendiğinde, araştırmaya katılan yönetici düzeyindeki personelin, etik karar verme alt boyutlarından sevgi boyutunun ( $\mathrm{U}=372,000 ; \mathrm{p}=0,517>0.05)$ ve adalet boyutunun $(\mathrm{U}=398,000 ; \mathrm{p}=0,785>0.05)$ medeni durum değişkenine göre anlamlı düzeyde farklılaşmadığ 1 tespit edilmiştir. İş birliği boyutunun $(U=372,000 ; p=0,049<0.05)$ ise anlamlı düzeyde farklılaştığı tespit edilmiştir. Sıra ortalamaları dikkate alındığında katılımcılardan evli olanların bekar olanlara göre etik karar alırken daha işbirlikçi olduklarını söylemek mümkündür. Bu yüzden H2 hipotezi kısmen ret kısmen kabul olmuştur.

Tablo 4. Araştırmaya Katılan Personellerin Etik Karar Verme Durumlarının Daha Önce Etik

Dersi Alma Durumuna Göre Karşılaştırılması Gösteren Mann Whitney U Testi Sonuçları

\begin{tabular}{lcccccc}
\hline & $\begin{array}{c}\text { Etik Dersi } \\
\text { Aldınız Mı? }\end{array}$ & $\mathbf{N}$ & $\begin{array}{c}\text { Sira } \\
\text { Ort. }\end{array}$ & $\begin{array}{c}\text { Sira } \\
\text { Top. }\end{array}$ & U & p \\
\hline Etik & Evet & 42 & 35,30 & 1482,50 & & \\
Karar & Hayır & 26 & 31,21 & 863,50 & 512,500 &, 672 \\
Verme & & & & & & \\
\hline $\mathrm{p}=0,05$ & & & & &
\end{tabular}


Tablo 4 incelendiğinde, araştırmaya katılan yönetici düzeyinde görev yapan personelin, etik karar verme durumlarının daha önce etik dersi alma değişkenine göre anlamlı düzeyde farklılaşmadığ1 $(\mathrm{U}=512,500 ; \mathrm{P}=0,672>0.05)$ sonucuna ulaşılmıştır. Bu yüzden H3 hipotezi ret olmuştur.

Tablo 5. Araştırmaya Katılan Personellerin Etik Karar Verme Durumlarının Yaşa Göre Karşılaştırılması Gösteren Kruskal Wallis Testi Sonuçları

\begin{tabular}{|c|c|c|c|c|c|c|c|c|}
\hline $\begin{array}{c}\text { Etik Karar } \\
\text { Verme }\end{array}$ & & Yaş & $\mathbf{N}$ & $\begin{array}{l}\text { Sira } \\
\text { Ort. }\end{array}$ & df & $\mathbf{X}^{2}$ & p & $\begin{array}{c}\text { Anlamli } \\
\text { Fark }\end{array}$ \\
\hline \multirow{3}{*}{ Sevgi Boyutu } & $\mathrm{A}$ & 25-34 Yaş & 14 & 33,25 & \multirow{3}{*}{2} & \multirow{3}{*}{1,900} & \multirow{3}{*}{,387 } & \multirow{3}{*}{ Yok } \\
\hline & B & 35-45 Yaş & 34 & 32,09 & & & & \\
\hline & $\mathrm{C}$ & 46-55 Yaş & 20 & 39,48 & & & & \\
\hline \multirow{3}{*}{$\begin{array}{l}\text { Adalet } \\
\text { Boyutu }\end{array}$} & $\mathrm{A}$ & 25-34 Yaş & 14 & 40,07 & \multirow{3}{*}{2} & \multirow{3}{*}{2,566} & \multirow{3}{*}{,277 } & \multirow{3}{*}{ Yok } \\
\hline & $\mathrm{B}$ & 35-45 Yaş & 34 & 31,06 & & & & \\
\hline & $\mathrm{C}$ & 46-55 Yaş & 20 & 36,45 & & & & \\
\hline \multirow{3}{*}{$\begin{array}{l}\text { İş birliği } \\
\text { Boyutu }\end{array}$} & $\mathrm{A}$ & 25-34 Yaş & 14 & 37,18 & \multirow{3}{*}{2} & \multirow{3}{*}{1,178} & \multirow{3}{*}{, 555} & \multirow{3}{*}{ Yok } \\
\hline & $\mathrm{B}$ & $35-45$ Yaş & 34 & 31,94 & & & & \\
\hline & C & 46-55 Yaş & 20 & 36,98 & & & & \\
\hline
\end{tabular}

$\mathrm{p}=0,05$

Tablo 5 incelendiğinde, araştırmaya katılan yönetici düzeyindeki personelin, yaş değişkenine göre etik karar verme durumlarının sevgi alt boyutunda $(p=0,387>0,05)$, adalet alt boyutunda $(\mathrm{p}=0,277>0,05)$ ve iş birliği alt boyutunda $(\mathrm{p}=0,555>0,05)$ anlamlı düzeyde farklılaşmadığ 1 belirlenmiştir. Bu yüzden $\mathrm{H} 4$ hipotezi ret olmuştur.

Tablo 6. Araştırmaya Katılan Personellerin Etik Karar Verme Durumlarının Göreve Göre Karşılaştırılması Gösteren Mann Whitney U Testi Sonuçları

\begin{tabular}{cclcccccc}
\hline & & Görev & N & $\begin{array}{c}\text { Sira } \\
\text { Ort. }\end{array}$ & df & $\mathbf{X}^{2}$ & p & Anlamlı \\
\hline Etik & A & Şb. Mdr. & 13 & 37,31 & & & & Fark \\
Karar & B & Daire Bşk. & 7 & 37,43 & & & & \\
Verme & & Lab. ve Araş. & 3 & & 11 & 17,178 &, 103 & Yok \\
& C & Mrk. Md. Yrd. & & 24,83 & & & & \\
& & & & & & &
\end{tabular}




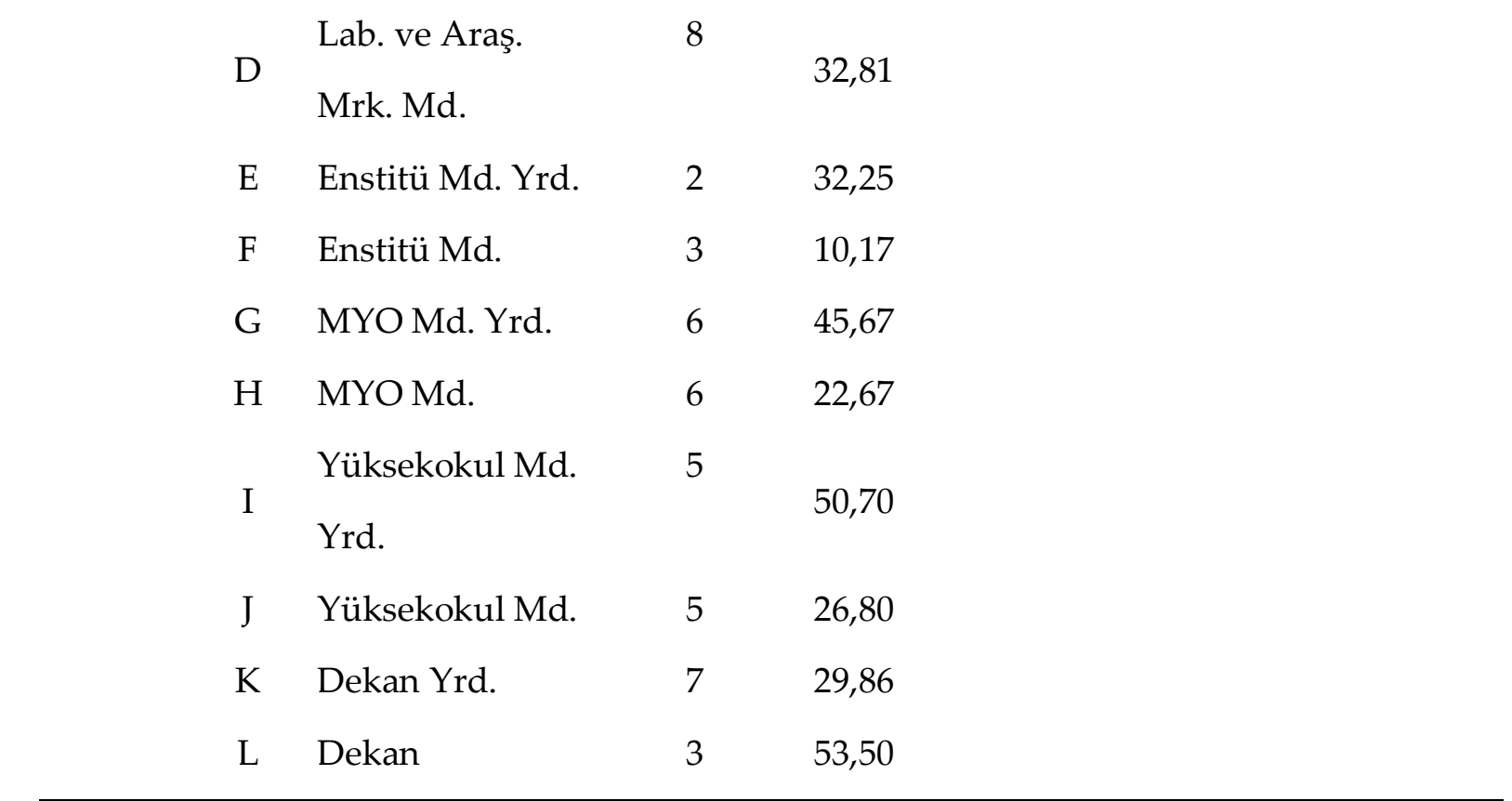

$\mathrm{p}=0,05$

Tablo 6 incelendiğinde, araştırmaya katılan yönetici düzeyinde görev yapan personelin etik karar verme durumlarının göreve değişkenine göre anlamlı düzeyde farklılaşmadığı $(\mathrm{p}=0,103>0.05)$ sonucuna ulaşılmıştır. Bu yüzden $\mathrm{H} 5$ hipotezi ret olmuştur.

Tablo 7. Araştırmaya Katılan Personellerin Etik Karar Verme Durumlarının Eğitim Durumuna Göre Karşılaştırılması Gösteren Kruskal Wallis Testi Sonuçları

\begin{tabular}{|c|c|c|c|c|c|c|}
\hline $\begin{array}{c}\text { Etik Karar } \\
\text { Verme }\end{array}$ & Eğitim Durum & $\mathbf{N}$ & Sira Ort. & Sira Top. & $\mathbf{U}$ & $\mathbf{P}$ \\
\hline \multirow{2}{*}{ Sevgi Boyutu } & Üniversite & 33 & 39,64 & 1308,00 & \multirow{2}{*}{408,000} & \multirow{2}{*}{, 034} \\
\hline & Lisansüstü & 35 & 29,66 & 1038,00 & & \\
\hline \multirow{2}{*}{ Adalet Boyutu } & Üniversite & 33 & 40,12 & 1334,00 & \multirow{2}{*}{392,000} & \multirow{2}{*}{, $017^{*}$} \\
\hline & Lisansüstü & 35 & 29,20 & 1022,00 & & \\
\hline \multirow{2}{*}{ İş birliği Boyutu } & Üniversite & 33 & 36,33 & 1199,00 & \multirow{2}{*}{517,000} & \multirow{2}{*}{450} \\
\hline & Lisansüstü & 35 & 32,77 & 1147,00 & & \\
\hline
\end{tabular}

$\mathrm{p}=0,05$

Tablo 7 incelendiğinde, araştırmaya katılan yönetici düzeyinde görev yapan personelin etik karar verme ölçeği alt boyutlarından sevgi boyutunun $(U=408,000 ; p=0,034<0.05)$ ve adalet boyutunun $(U=392,000 ; p=0,017<0.05)$ eğitim durumu değişkenine göre anlamlı düzeyde farklılaştığı, iş birliği boyutunun ( $U=517,000 ; p=0,450>0.05)$ eğitim durumu değişkenine göre anlamlı düzeyde farklılaşmadığ tespit edilmiştir. Etik karar verirken üniversite mezunlarının sevgi boyutunda ve adalet boyutunda, lisansüstü mezunlara göre daha etik karar aldıkları sonucuna ulaşılmıştır. Bu yüzden H6 hipotezi kısmen ret kısmen kabul olmuştur. 


\section{Sonuç ve Öneriler}

Bir konunun birbiri ile çatışma halinde olan iki farklı yönünün belirlenmesi ve bu iki yönün doğru olduğu tartışılabilir taraflarının olması şeklinde ifade edilirken; etik olmayan kararlar verilmesi de etik sapma şeklinde tanımlanır (İşgüden ve Çabuk, 2006). Araştırmada, Ağrı İbrahim Çeçen Üniversitesi'nde yönetici düzeyinde görev yapan personelin etik karar verme durumlarının farklı değişkenler açısından belirlenmesi amaçlanmış ve şu sonuçlara ulaşılmıştır:

Araştırma bulguları incelendiğinde, yönetici düzeyinde görev yapan personelin etik karar verme algılarının cinsiyete göre değişmediği yani cinsiyet değişkenin etik karar vermeyi etkilemediği sonucuna ulaşılmıştır. Turan Vd. (2005) tarafından yapılan Üniversite Yöneticilerinin Benimsedikleri İdari ve Kültür Değerler başlıklı çalışmada benzer şekilde etik karar vermenin cinsiyet faktöründen etkilenmediği sonucuna ulaşılmıştır. Bu durum çalışmadaki bulgularla da uyuşmaktadır.

Evli olan yönetici düzeyindeki personelin etik kararlar verirken daha işbirlikçi olduklarını söylememiz mümkündür. Araştırma bulgularına göre daha önce etik dersi almış olmanın etik davranma üzerinde herhangi bir etkisi olmadığı görülmüştür. Yaş değişkenin ve görev değişkeninin etik karar verme üzerinde herhangi bir etkisinin olmadığ1 sonucuna ulaşılmıştır. Üniversite mezunu olan yönetici düzeyindeki personelin etik karar verirken daha sevgi dolu ve adaletli davrandığı tespit edilmiştir. Araştırmanın farklı örneklem grubu ile farklı kurumlarda yapılmasının farklı sonuçlar çıkaracağı düşünüldüğünden; araştırmacılara bu yönde öneride bulunulabilir.

\section{Kaynakça}

Banks, S. (2006). Ethical and values in social work. Third Edition. London: Macmillan Press.

Billington, R. (2001). Felsefeyi Yaşamak ahlâk düşüncesine giriş. İstanbul: Ayrıntı Yayınları.

Creswell, J. W. (2013). Araştırma Deseni: Nitel, Nicel ve Karma Yöntem Yaklaşımları. (Çev. Selçuk Beşir Demir). Ankara: Eğiten Kitap.

Daştan, A., Bayraktar Y., Bellikli U., (2015), 'Muhasebe Mesleğinde Etik İkilem ve Etik Karar Alma Konularında Farkındalık Oluşturma: Trabzon İlinde Bir Araştırma', Atatürk Üniversitesi İ̈BF Dergisi, 29 (1): 63-82.

Ercan, G., Ercan, G., \& Altunay, E. (2015). İlkokul ve Ortaokul Yöneticilerinin Kişilik Özellikleri İle Karar Verme Becerileri Arasındaki İlişkinin İncelenmesi (İzmir İli Örneği)*. Ondokuz Mayıs Üniversitesi Eğitim Fakültesi Dergisi, 34(2), 120-143.

Erim, G. (2018). Kamu Yönetiminde Etik Anlayışı: Türk Kamu Yönetimi ve İngiliz Kamu Yönetiminde Etik Uygulamaların Karşılaştırmalı Analizi. Yüksek Lisans Tezi. Selçuk Üniversitesi, Sosyal Bilimler Enstitüsü. Konya.

Erkuş, A. (2013). Davranış bilimleri için bilimsel araştırma süreci. Ankara: Seçkin Yayın.

Eryılmaz, B., (2015). Kamu Yönetimi (8. Baskı). Kocaeli: Umuttepe Yayınları.

Gerçek, M. (2017), 'Etik İklim ve Örgütsel Güvenin Üretkenlik Karşıtı Davranışlar Üzerindeki Etkisinin İncelenmesi’, Uluslararası Sosyal Araştırmalar Dergisi, 10 (51): 953-963. 
Gökçearslan Çifçi, E., Gönen, E. (2011), 'Sosyal Hizmet Uygulamalarında Etik Karar Verme Süreci', Toplum ve Sosyal Hizmet Dergisi, 22 (2): 149-160.

Gönen, E. (2002). Ev İdaresi İlkeleri. 3. Bas-kı. Ankara: Ankara Üniversitesi Ev Ekonomisi Yüksekokulu Yayın No: 3, Ders Kitabı:1.

Gül, Ş., Duru-Aşiret, G., Bayrak Kahraman, B., Devrez, N., Örnek Büken, N. (2013). Etik Dersi Alan ve Almayan Hemşirelik Öğrencilerinin Etik Karar Verebilme Düzeylerinin İncelenmesi. Turkish Journal of Research \& Development in Nursing, 15(1).

İşgüden, B., Çabuk A., (2006), “Meslek Etiği ve Meslek Etiğinin Meslek Yaşamı Üzerindeki Etkileri”, Balıkesir Üniversitesi Sosyal Bilimler Enstitüsü Dergisi, Sayı:16, ss. 59-86.

Kaya İ. "Etik Değerlere Yatkınlık Ölçeği: Geçerlik ve Güvenirlik Çalışması". Uluslararası Sosyal Araştırmalar Dergisi. c.8. s.41 (2015): 968-974.

Lo, B. (1995). Resolving ethical dilemmas: A guide for clinicians. Maryland: Williams\&Wilkins.

Turan, S., Durceylan, B., \& Şişman, M. (2005). Üniversite yöneticilerinin benimsedikleri idari ve kültürel değerler. Manas Üniversitesi Sosyal Bilimler Dergisi, 13, 181-202.

Özdemir, E., (2009), 'Pazarlama Araştırmasında Etik Karar Alma', Ankara Üniversitesi SBF Dergisi, 64 (2): 119-144.

Sabuncuoğlu, Z., (2011), İşletme Etiği, 1.Baskı, Beta Basım Yayın, İstanbul. 